IDIOPATHIC

RECURRENT

CYSTITIS:

A UROGYNAECOLOGICAL DILEMMA
CISTITE RICORRENTE IDIOPATICA: DILEMMA UROGINECOLOGICO

\title{
E. MANTOVANI
}

Clinica Urologica - Università di Milano

\section{INTRODUCTION}

During the first episode of cystitis, the general tendency is to proceed directly with treatment, postponing diagnosis, precisely because it is the first episode, and due to the impressiveness of the symptoms of acute cystitis, and also in the implicit hope that it may be an isolated episode that does not repeat itself. The usual recommendation is rest, abstention from sexual activity, and a mineral water cure. Wide spectrum antiseptic, anti-inflammatory, antispasmodic drugs and painkillers are prescribed. If, despite this, and perhaps after a short period of time, the episode relapses, a diagnosis should be performed. We are consequently dealing with Recurrent Cystitis. The laborato-

\section{INTRODUZIONE}

In occasione del primo episodio di cistite si tende a passare direttamente al trattamento soprassedendo alla diagnostica, sia perché si tratta appunto del primo episodio, sia per l'imponenza della sintomatologia nella cistite acuta, che per l'implicito augurio possa trattarsi di un episodio circoscritto e senza repliche. Si consiglia riposo, astensione dall'attività sessuale, idropinoterapia. Si prescrivono antisettici ad ampio spettro, antiflogistici, antispastici, antidolorifici. Se tuttavia, e magari a breve distanza di tempo, l'episodio recidiva le cose dovrebbero cambiare, privilegiando la diagnostica. Si entra così nel campo delle Cistiti Ricorrenti. Le indagini di laboratorio ricercheranno, sia a fresco 
ry tests will look for pathogenic micro-organisms in the urine, both fresh and in culture, as well as in vaginal secretions and in the urethral duct, including the ones that are difficult to discover. The diagnosis will also take into consideration serum with glycaemia, in search of latent diabetes capable of sustaining urinary tract infections and above all their recurrence; a blood count to ascertain any immune deficits, which may also encourage the recurrence of urinary tract infections. An ultrasound examination of the urinary system could reveal hydronephrosis, perhaps lithiasic, acting as a receptacle for the production of infected urine. Urethrocystography could reveal vesico-urethral reflux or a diverticulum of the urethra, which could also be the cause of the recurrent urinary tract infections. Lastly, an endoscopic examination (urethrocystoscopy) could reveal other causes of cystitic symptoms, such as leukoplakia of the trigonum, interstitial cystitis or more unfortunately a carcinoma in situ by means of a biopsy. Once the diagnosis identifies the cause, an aetiological remedy can then be found. The therapy will consequently be aimed at the causal factor of the disease. Pharmacological, rather than endoscopic or surgical treatment can be attempted depending upon the reasons underlying the reappearance of the symptoms of the inflammatory bladder disease. However when the cause defies identification, as it is frequently the case, and the symptoms persist or relapse, we enter into a field referred to as Idiopathic Recurrent Cystitis (I.R.C.). An extremely limited number che in coltura, microrganismi patogeni nelle urine, ma anche nei fluidi vaginali e nel lume uretrale, compresi quelli di difficile rinvenimento. Non verrà trascurata la diagnostica su siero con la glicemia, alla ricerca di un diabete latente favorente le infezioni delle vie urinarie e soprattutto la loro recidivanza; un emocromo con formula per accertare eventuali deficit immunitari, anch'essi favorenti la ricorrenza delle infezioni delle vie urinarie. L'ecografia dell'apparato urinario potrà evidenziare una misconosciuta idronefrosi, magari calcolotica, facente da serbatoio alla produzione di urine infette. L'uretrocistografia potrà evidenziare un reflusso vescicoureterale o un diverticolo dell'uretra, altrettante cause di infezioni recidivanti delle vie urinarie. Infine l'indagine endoscopica (uretrocistoscopia) potrà evidenziare altre cause di sintomatologia cistitica, come una placca leucoplasica del trigono, una cistite interstiziale o più sfortunatamente un carcinoma in situ attraverso una biopsia. Quando la diagnostica identifica una causa potremmo allora trovare un rimedio etiologico; la terapia sarà quindi mirata al fattore causale della malattia. Si potrà sperimentare una terapia farmacologica piuttosto che endoscopica o chirurgica a seconda delle motivazioni alla base delle riprese sintomatologiche della malattia infiammatoria vescicale. Quando tuttavia, e non è infrequente, la causa non soggiace a identificazione, e per contro la sintomatologia persiste o recidiva, si entra in quella "terra di nessuno" costituita dalla Cistite Ricorrente Idiopatica (C.R.I.). Allo studio, alla diagnosi e alla cura di tale affezione 
of urologists and gynaecologists devote themselves to studying, diagnosing and treating this disorder which plagues a very much larger number of women than one would imagine, especially young women at the height of their family and working activity. This is due to the difficulty in interpreting the disease itself, in addition to the further difficulties in solving it, as well as to the moodiness of these patients, undoubtedly not due to their character, but to the strain caused by a disease which appears to be unsolvable from a diagnostic, and especially a therapeutic point of view, and in time ends by physically, as well as existentially and psychologically wearing out those who have to endure it.

\section{EPIDEMIOLOGICAL, CLINICAL AND DIAGNOSTIC ASSESSMENT}

Idiopathic Recurrent Cystitis is a very often under-diagnosed disease, since its insidious onset causes frequent diagnostic mistakes or underestimation of the pathology in progress.

Idiopathic Recurrent Cystitis takes the shape of a syndrome characterised by severe pollakiuria, imperative urination, perineal pain and/or hypogastric pain, occasional haematuria (Table I). che tormenta un numero di donne molto più considerevole di quanti non si immagini, soprattutto di giovani e nel pieno dell'attività familiare e lavorativa, si dedicano una stretta minoranza di urologi e ginecologi, per le difficoltà interpretative dell'affezione stessa alle quali si sommano ulteriori difficoltà risolutive e anche per la caratterialità di queste pazienti, non certo dovuta alla loro natura, ma al logorio che comporta un morbo del quale non si riesce a venirne a capo dal punto di vista diagnostico, ma soprattutto terapeutico e che nel tempo finisce per esaurire chi lo deve sopportare dal punto di vista fisico, ma anche esistenziale e psicologico.

\section{INQUADRAMENTO EPIDEMIOLOGICO, CLINICO E DIAGNOSTICO}

La Cistite Ricorrente Idiopatica è una malattia spesso sottodiagnosticata poiché la sua insorgenza insidiosa è la causa di frequenti errori diagnostici o di sottovalutazione della patologia in atto.

La Cistite Ricorrente Idiopatica si presenta come una sindrome caratterizzata da grave pollachiuria, minzione imperiosa, dolore perineale e/o dolore ipogastrico, occasionale ematuria (Tab. I). 
Table I - Organic symptoms of I.R.C.

\section{I.R.C. ORGANIC SYMPTOMS}

Imperative urination

Pollakiuria

Pelvic pain

Pelvic pressure

Bladder spasm

Pain during sexual intercourse

Pain for days after sexual intercourse

Burning sensation

Blood in the urine

Disturbed sleep due to pain

Sensation of a full bladder after urinating

The endoscopic picture may reveal inflammatory lesions which look like small patches of whitish red mucosa surrounded by congested vessels.

Idiopathic Recurrent Cystitis is a highly debilitating pathology. Almost 90\% of those affected are women, however such a low incidence in men could once again be ascribed to a diagnostic error, seeing that in males the symptoms of Idiopathic Recurrent Cystitis could easily be mistaken for those of prostatitis.

Numerous causes have been taken into consideration: chronic infections, auto-immune diseases, vascular disorders, lymphatic obstructions and neurological/psychological disorders.

Nowadays, it is quite widely accepted that patients with a considerably reduced bladder capacity and severe bladder pains, and with urgent and very frequent need to urinate
L'immagine endoscopica può presentare lesioni flogistiche che appaiono come piccole chiazze di mucosa rosso biancastra, circondate da vasi congesti. La Cistite Ricorrente Idiopatica è una patologia altamente debilitante; quasi il 90\% degli affetti sono donne, ma una così bassa incidenza negli uomini potrebbe tuttavia essere imputata ancora una volta a un errore diagnostico, visto che nel maschio i sintomi della Cistite Ricorrente Idiopatica potrebbero essere facilmente confusi con quelli della prostatite.

Molte cause sono state prese in considerazione: infezioni croniche, malattie autoimmuni, vasculopatie, ostruzioni linfatiche e disturbi neurologici/psicologici. Attualmente, è abbastanza ampiamente accettato che i pazienti con una capacità vescicale notevolmente ridotta e gravi dolori alla vescica, con urgenza e notevole frequenza delle minzioni (non meno 
(not less than 8 times, with an average of 16 times during the day and not less than twice during the night), can be considered as suffering from Idiopathic Recurrent Cystitis.

Fortunately, it is a pathological condition which only very rarely has a fatal outcome. Yet it is an extremely debilitating syndrome, which quite often leaves after-effects of a neuropsychiatric nature (Table II). di 8 volte, con una media di 16 volte durante il giorno e non meno di 2 volte durante la notte), possano essere considerati affetti da Cistite Ricorrente Idiopatica.

Fortunatamente è una patologia che solo raramente porta a esiti fatali; pur tuttavia è una sindrome estremamente debilitante, che non di rado lascia strascichi di carattere neuropsichiatrico (Tab. II).

Table II - Psychotic symptoms. Percentage frequency

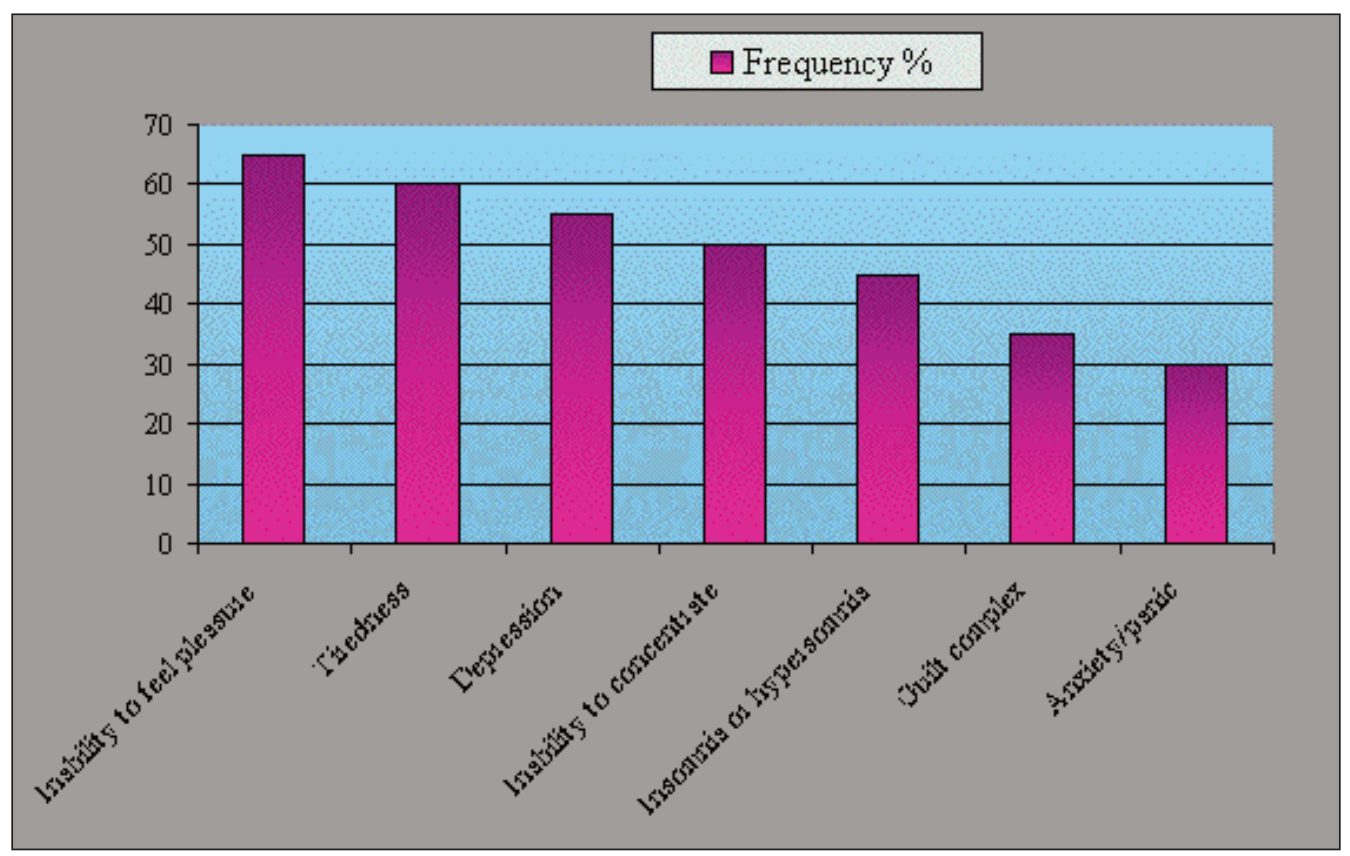

The average age at which I.R.C. first occurs is around 40 (approximately $25 \%$ of patients are under 30 years of age). Due to the severity of the symptoms, about $50 \%$ of the patients are unable to carry out a fulltime job; 60\% report pain during sexual intercourse, to the point of reduc-
L'età media d'insorgenza è intorno ai 40 anni (circa il 25\% ne ha meno di 30). Il 50\% circa dei pazienti, per la gravità dei sintomi, non riesce a svolgere un lavoro a tempo pieno; il $60 \%$ segnala la presenza di dolore durante i rapporti sessuali, tanto da ridurne la frequenza fino all'astinen- 
ing the frequency or even abstaining from sexual intercourse. Idiopathic Recurrent Cystitis is an inflammatory bladder condition of unknown aetiology, which is difficult to treat and is seldom curable. The main symptoms are an exacerbation of the normal feeling of discomfort induced by the need to urinate, which everyone has experienced. Diagnosing this pathology, in the absence of the confirmation of a specific pathology, is particularly difficult.

The diagnosis of Idiopathic Recurrent Cystitis is consequently ascertained by the process of elimination, and is based essentially upon the symptoms, after having ruled out any possible causal factors by means of accurate laboratory tests, as well as ultrasound and endoscopic examinations.

\section{THERAPEUTIC RESOURCES}

Since Idiopathic Recurrent Cystitis is a pathology with an as yet not precisely defined aetiology, various pharmacological (oral and intravesical) therapeutic strategies have been adopted. In recent times, starting from one of the latest and most reliable theories, according to which Idiopathic Recurrent Cystitis also results from a defect of the mucous membrane lining the wall of the bladder, the use of Hyaluronic Acid has been proposed in the treatment of this pathology. Hyaluronic Acid is one of the main polysaccharides forming the extracellular matrix of most tissues and is widely distributed in almost all body fluids. za. La Cistite Ricorrente Idiopatica è uno stato infiammatorio della vescica a etiologia sconosciuta, difficilmente trattabile e raramente curabile. I principali sintomi sono effettivamente delle esasperazioni della normale sensazione di disagio indotta dal bisogno di urinare, che ognuno ha sperimentato. Diagnosticare questa patologia, in assenza di specifici riscontri patologici, è particolarmente difficile.

La diagnosi di Cistite Ricorrente Idiopatica si pone pertanto per esclusione, basandosi essenzialmente sui sintomi, dopo aver escluso con accurate indagini laboratoristiche, ecografiche ed endoscopiche, ogni possibile fattore causale.

\section{RISORSE TERAPEUTICHE}

Poiché la Cistite Ricorrente Idiopatica è una patologia dall'etiologia ancora non esattamente definita, sono state adottate differenti strategie terapeutiche farmacologiche (orali e intravescicali). Negli ultimi tempi, partendo da una delle più accreditate e recenti teorie, la quale afferma che la Cistite Ricorrente Idiopatica sia conseguente anche a un difetto del rivestimento mucoso della parete vescicale, è stato proposto l'uso dell' Acido Jaluronico nel trattamento di questa patologia. L'Acido Jaluronico è uno dei principali mucopolisaccaridi componenti la matrice extracellulare della maggior parte dei tessuti ed è anche ampliamente distribuito in quasi tutti 
Hyaluronic Acid is one of the most important glycosaminoglycans (GAG) found in all connective tissues, including the layer of GAG in the mucous membrane of the bladder (1). Consequently, it is believed that administration by intravesical instillation may help restore the impermeable layer of urothelial mucin, by restoring the integrity of the protective lining of glycosaminoglycans. In fact, the urothelial layer of GAG forms a barrier against micro-organisms, carcinogenic substances, proteins and ionic residues present in the urine. Glycosaminoglycans have been identified as being responsible for the main defence mechanism of the vesical epithelium against all the irritating substances concentrated in the urine.

\section{APPLICATION PROTOCOL}

The treatment contemplates instillation of $40 \mathrm{mg} / 50 \mathrm{ml}$ of sodium hyaluronate (Cystistat-Zambon) into the bladder once a week for 1 month and then once a month for 3-6 months depending on the degree of remission. The instillations are not excessively onerous, but may prove ineffective if the preparation does not remain in the bladder long enough at the right concentration.

Since diuresis gives rise to dilution and the impelling need to urinate, typical of these patients, and therefore the premature expulsion of the pharmaceutical preparation, an expedient that can be adopted consists in preceding the instillation by a few i fluidi corporei.

L'Acido Jaluronico è uno dei più importanti glicosaminoglicani (GAG) presente in tutti i tessuti connettivi, incluso lo strato dei GAG nella mucosa vescicale (1). Si ritiene quindi che la somministrazione tramite instillazione intravescicale possa favorire il ripristino dello strato di natura impermeabilizzante di mucina uroteliale, mediante appunto la ricostituzione dell'integrità del rivestimento protettivo di glicosaminoglicani. Lo strato di GAG uroteliale costituisce infatti una barriera contro microrganismi, sostanze cancerogene, proteine o residui ionici presenti nelle urine. I glicosaminoglicani sono stati identificati quali responsabili appunto del principale meccanismo di difesa dell'epitelio vescicale da tutte le sostanze irritanti concentrate nell'urina.

\section{PROTOCOLLO APPLICATIVO}

Il trattamento contempla l'instillazione vescicale di $40 \mathrm{mg} / 50 \mathrm{ml}$ di jaluronato di sodio (Cystistat-Zambon) la settimana per 1 mese e quindi una volta al mese per $3 / 6$ mesi in base la grado di remissione.

Le instillazioni non sono eccessivamente onerose, ma possono risultare inefficaci se il preparato non permane adeguatamente a lungo in vescica alla giusta concentrazione.

Poiché la diuresi comporta la diluizione e l'impellenza minzionale tipica di questi pazienti, la precoce espulsione del farmaco, è adottabile l'accorgimento di anticipare l'instillazione di alcune ore con l'assunzione di Vasopressina spray nasale (Minirin- 
hours with administration of Vasopressin nasal spray (Minirin-Ferring) which, by inducing temporary anuria, solves these drawbacks. To anticipate and boost the efficacy of the treatment, in view of the phobic desire of these patients to recover, a targeted L-Arginine and Polyphenol-based oral pharmacotherapy can usefully be used in conjunction.

L-Arginine (Bioarginine-Damor) is the precursor of nitric oxide synthetase. Nitric oxide (NO) is an extremely active smooth muscle relaxant.

By chemical-physical law the excess administration [2gr/20ml x 2/day] of a precursor (L-Arginine) catalyses the synthesis of the end product (NO) increasing its availability.

Nitric oxide would prove to be extremely advantageous in antagonising detrusorial hyperexcitability and contractility (2), resulting in an increase in vesical compliance and a consequent attenuation of the urgency/frequency, a true scourge for these patients.

Polyphenols (Uticran-Bradel) [15mg x 2/day] are active principles of plant origin, which by means of the dual effect of acidification and inhibition of bacterial adherence possess the most suitable properties for integrating the action of hyaluronic acid in Idiopathic Recurrent Cystitis with particular features as alkaline $\mathrm{pH}$, positive nitrites and abundant sediment (3).

24 patients with an average age of 44 years were treated with this protocol, with a 1-year follow up.
Ferring) che inducendo una transitoria anuria risolve tali handicaps.

Per anticipare e potenziare l'efficacia del trattamento, data la fobica ansia di guarigione di questi pazienti, è utilmente associabile una farmacoterapia orale mirata a base di L-Arginina e Polifenoli.

La L-Arginina (Bioarginina-Damor) è il precursore della ossidonitrico-sintetasi. Il Nitrossido (NO) è un rilassante estremamente attivo della muscolatura liscia.

Per legge chimico-fisica la somministrazione in eccesso [ $2 \mathrm{gr} / 20 \mathrm{ml}$ per 2/die] di un precursore (L-Arginina) catalizza la sintesi del prodotto finale (NO) aumentandone la disponibilità.

Il Nitrossido risulterebbe quanto mai proficuo nell'antagonizzare l'ipereccitabiltà e contrattilità detrusoriale (2), incrementando la compliance vescicale e con conseguente attenuazione dell'urgenza/frequenza, vero flagello di questi pazienti.

I Polifenoli (Uticran-Bradel) [15mg per 2/die] sono principi attivi di derivazione vegetale che attraverso il duplice effetto di acidificazione e inibizione dell'adesività batterica presentano le più idonee prerogative per integrare l'azione dell'acido jaluronico nelle Cistiti Ricorrenti Idiopatiche con $\mathrm{pH}$ alcalino, nitriti positivi e abbondante sedimento (3).

Con tale protocollo sono state trattate $\mathrm{n}^{\circ} 24$ pazienti, età media 44 anni, con follow up di 1 anno. 


\section{RESULTS}

The patients were evaluated essentially on the basis of the basis of a questionnaire (filled in at the time of recruitment and then at 1,3 and 6 months from the start of treatment) validated in order to ascertain to what extent (slightly, moderately, highly) the disorders (frequency, nycturia, urgency, incontinence, pain, incontinence pads, sociality, sexuality) had changed with the therapy. All 24 of the patients tolerated and completed the therapeutic protocol at 6 months: only 4 declared that they had fully recovered, while 8 were found to be improved and 12 unchanged.

Upon re-proposing the questionnaire after 6 months of non-therapy, the response revised the data as follows: the 4 fully recovered patients now declared to be only improved, as did 4 of the group of unchanged patients, who went to join the 8 who continued to be improved. Hence, the therapeutic protocol after 6 months of treatment and 6 months of follow up produced: 16 improved out of 24 and 8 unchanged.

\section{CONCLUSIONS}

The absence of a comparison with placebo, as well as the relatively small number of cases treated, and shortness of the follow up may constitute the shortcomings of this study, which nevertheless would be difficult for anyone to conduct, in clinical practice, according to such classical rationales, in view of the undeniable peculiarity of the pathology and the

\section{RISULTATI}

Sono stati valutati essenzialmente in base a un questionario (somministrato all'arruolamento e quindi a 1,3 e 6 mesi dall'inizio del trattamento) validato per accertare in che misura (poco, moderatamente, molto) si erano modificati i disturbi (frequenza, nicturia, urgenza, incontinenza, dolore, pannoloni, socialità, sessualità) con la terapia. Tutte le 24 pazienti completarono, ben tollerandolo, il protocollo terapeutico a 6 mesi: solo 4 si dichiararono guarite, mentre 8 risultarono migliorate e 12 invariate.

Riproponendo il questionario dopo 6 mesi di non terapia il responso rimaneggiava i dati nel modo seguente: le 4 pazienti guarite si dichiaravano ora solo migliorate, così pure 4 del gruppo delle invariate andandosi ad associare alle 8 che persistevano migliorate. Così il protocollo terapeutico dopo 6 mesi di applicazione e 6 di follow up aveva prodotto: $16 \mathrm{mi}-$ gliorate su 24 e 8 invariate.

\section{CONCLUSIONI}

Assenza di confronto con placebo, relativa esiguità della casistica, brevità del follow up possono costituire lacune di questo studio che tuttavia sarebbe arduo per chiunque da condurre, nella pratica clinica, secondo tali classici razionali, scontrandosi con l'indiscutibile peculiarità della patologia e delle pazienti. Il protocollo terapeutico che presentiamo non sembra 
patients. The therapeutic protocol which we are presenting does not appear to lead to recovery, but neither does it lead to exacerbation, and over $60 \%$ of substantial and stable improvement in terms of quality of life at one year does not in all honesty appear to be a negligible result in aid of this unfortunate category of patients suffering from a benign albeit malefic disease. produrre guarigioni, ma nemmeno peggioramenti e oltre il 60\% di sostanziali miglioramenti stabili per qualità di vita a un anno non sembra onestamente un risultato trascurabile in soccorso a questa sfortunata categoria di pazienti affetta da una malattia benigna quanto malefica.

\section{REFERENCES}

1 - PARSON C.L., BOYCHUK D., JONES S., HURST R. and CALLAHAN H.:

Bladder surface glycosaminoglycans: an epithelial permeability barrier. J Urol 1990; 143: 139-142

2 - SMITH S.D., WHEELER M.A., FOSTER HE Jr., WEISS R.M. : Efficacy of oral l-arginine treatment for interstitial cystitis. J Urol 1996; 155: 439 A

3 - SOBOTA A.E. :

Inbibition of bacterial adberence by Cranberry juice: potential use for the treatment of urinary tract infections.

J Urol 1983; 131: 1013 